\title{
Penile Basal Cell Carcinoma
}

National Cancer Institute

\section{Source}

National Cancer Institute. Penile Basal Cell Carcinoma. NCI Thesaurus. Code C39961.

A basal cell carcinoma of the penis with an indolent clinical course. It is usually superficial and arises from the shaft and rarely the glans. 